\title{
Thermal Expansion of LX-17, PBX 9502 and Ultrafine TATB
}

P. C. Souers, P. Lewis, M. Hoffman and B. Cunningham

September 23, 2010 
This document was prepared as an account of work sponsored by an agency of the United States government. Neither the United States government nor Lawrence Livermore National Security, LLC, nor any of their employees makes any warranty, expressed or implied, or assumes any legal liability or responsibility for the accuracy, completeness, or usefulness of any information, apparatus, product, or process disclosed, or represents that its use would not infringe privately owned rights. Reference herein to any specific commercial product, process, or service by trade name, trademark, manufacturer, or otherwise does not necessarily constitute or imply its endorsement, recommendation, or favoring by the United States government or Lawrence Livermore National Security, LLC. The views and opinions of authors expressed herein do not necessarily state or reflect those of the United States government or Lawrence Livermore National Security, LLC, and shall not be used for advertising or product endorsement purposes.

This work performed under the auspices of the U.S. Department of Energy by Lawrence Livermore National Laboratory under Contract DE-AC52-07NA27344. 


\title{
Thermal Expansion of LX-17, PBX 9502 and Ultrafine TATB
}

\author{
P. Clark Souers*, Pat Lewis, Mark Hoffman and Bruce Cunningham \\ Energetic Materials Center, Lawrence Livermore National Laboratory, Livermore, CA 94550 (USA) \\ * Corresponding author; e-mail: souers1@1lnl.gov
}

\begin{abstract}
A large quantity of linear strain and LCTE data from $-55^{\circ} \mathrm{C}$ to $75^{\circ} \mathrm{C}$ on LX-17, PBX 9502 and ultrafine TATB (ufTATB) is presented. Axial and diametral measurements are blended to give final densities, which agree with the liquid immersion values of Baytos, et. al. The nominal densities at $21,-55$ and $75^{\circ} \mathrm{C}$ in $\mathrm{g} \mathrm{cm}^{-3}$ are: LX-17 1.90, 1.920 , 1.874; PBX 9502 1.89, 1.907, 1.867; ufTATB 1.80, 1.822, 1.778. Data taken radially show more thermal expansion than that taken transversely in cut-up parts; both must be combined to get the density. There is no difference between virgin and recycled TATB. Rachet growth data is presented, both at low pressure and at higher pressure, where the swelling is diminished. A Kel-F strain curve is presented and the theoretical maximum densities are computed.
\end{abstract}

Keywords: density, thermal expansion, LCTE, strain

\section{Introduction}

The thermal expansion of high-\% TATB explosives has been measured for 30 years and still questions persist. The major explosives are LX-17 (wet-aminated TATB 92.5 wt\%/kel-F 7.5), PBX 9502 (dryaminated TATB 95\%/kel-F 5) and ultrafine TATB (ufTATB; wet-aminated), which is used as a booster. The type of amination refers to the last step in the production synthesis of the TATB made 30 years ago. Dry-aminated TATB has $0.8 \%$ ammonium chloride left from the process whereas wet-aminated TATB has $0.1 \%$. The Micromeritics Saturn 5200 DigiSizer was used to measure the particle sizes by laser light scattering, and the results are shown in Figure 1. Basic wet and dry-aminated TATB have a mean size of about $75-80 \mu \mathrm{m}$, but ultrafine TATB has been micronized to bi-modal peaks at 0.3 and $8 \mu \mathrm{m}$. 


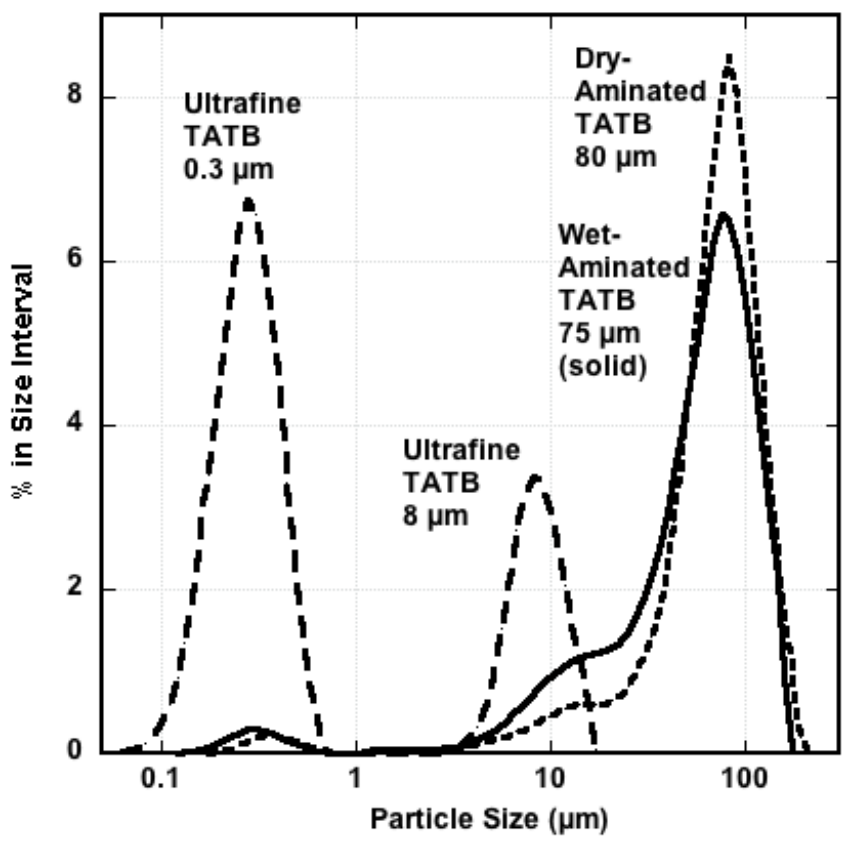

Figure 1. Particle size distribution for three kinds of TATB.

Rizzo, Humphrey and Kolb measured the linear coefficient of thermal expansion (LCTE) of TATB and LX-17 and found it varied as a function of grain size and pressing method [1,2]. Further, they found that thermal cycling of small parts caused them to swell in a phenomenon called rachet growth. Cady was perhaps the first to make large parts, cut them up, and to discover that LCTE's measured parallel to a radius are different from those measured transversely [3]. The field was summarized by Skidmore [4], who labeled the PBX 9502 LCTE's as "elusive" and showed a $\pm 20 \times 10^{-6}{ }^{\circ} \mathrm{C}^{-1}$ variation in the literature LCTE's. Not included in Skidmore were important immersion densities of PBX 9502 done by Baytos and Martinez [5].

The Skidmore review [4] points out that almost all thermal expansion data has been presented in terms of LCTE's. This seems to have derived from the study of metals, where the LCTE's are fairly constant with temperature. For explosives, they are not, although early work sought to define them as constant over limited temperature ranges. LCTE's contain some error caused by performing another step on the original data, but the historical desire to somehow make LCTE's seem constant is a larger problem in considering old data.

Our particular interest is to obtain density data at specific cold and elevated temperatures for inclusion into a computer code. Immersion measurements speak directly to this. Because thermal mechanical analyzers (TMAs) generally only measure thickness changes in a single direction, multiple measurements 
must be made in order to characterize a material's anisotropic behavior. The expansion data from these separate experiments must then be combined to estimate volumetric, and subsequently, density changes.

Assuming constant mass, and if the sample is isotropic, we can convert the relative linear strain, $\mathrm{S}_{\mathrm{l}}$, at some temperature to density at that temperature, $\rho_{\mathrm{T}}$, by using the expression

$$
\rho_{T}=\frac{\rho_{o}}{1+3 S_{l}}
$$

where $\rho_{o}$ is the initial reference temperature density. For samples ram-pressed as cylinders, the strain in the axial direction of the cylinder is different from that at right angles- the diametral direction. The two results may be averaged using

$$
\left\langle S_{l}\right\rangle=\frac{1}{3}\left[S_{l}(\text { axial })+2 S_{l}(\text { diametral })\right]
$$

This value can be used in Eq. (1) in place of $\mathrm{S}_{\mathrm{l}}$, and a similar expression would apply to LCTE's as well. Other samples are pressed as hemispheres but are cut up into cylinders. These pieces are measured axially, but the sample axis could have been aligned either along the complete part-radius (radial) or perpendicular to the complete part-radius (transverse). The average of the two directions is computed the same way in Eq. (3).

$$
\left\langle S_{l}\right\rangle=\frac{1}{3}\left[S_{l}(\text { radial })+2 S_{l}(\text { transverse })\right]
$$

Axial/diametral and radial/transverse are similar but refer to the individual cylinder part and the complete part from which the cylinder may have come. Many samples were cylinders with lengths and radii varying from 6.35 to $20 \mathrm{~mm}$. Some were rectangular solids with dimensions varying from 3 to $63.5 \mathrm{~mm}$.

\section{Experimental}

Most of our measurements reported here were done with a TA Instruments 2940 thermal mechanical analyzer. In this instrument, the expansion of the sample causes a core attached to a quartz rod probe to move inside a coil, causing a change in voltage. The instrument is calibrated using factory-supplied aluminum standards, which are run over a temperature range of $47^{\circ} \mathrm{C}$ to $147^{\circ} \mathrm{C}$. In addition, $6061 \mathrm{~T}-6$ aluminum samples were measured from $-60{ }^{\circ} \mathrm{C}$ to $150{ }^{\circ} \mathrm{C}$, and the results agreed with the data of Nix and 
McNair [6]. Also, a Digital Image Correlation (DIC) machine is now also being used, and results from it agreed with Nix and McNair's aluminum from $25^{\circ} \mathrm{C}$ to $75^{\circ} \mathrm{C}$. This optical method can see the tiny strain of ZeroDur glass, albeit with scatter. A few measurements were made with an Ares G2 mechanical spectrometer, which was not designed to do thermal expansion. This was calibrated against Nix and McNair aluminum [6], with the correction being about half the measured strain. It was further calibrated by running the same LX-17 sample on the Ares and on the DIC, so that the LX-17 became a secondary standard. The Ares is good for looking for major possible changes in thermal expansion.

All of our data was taken with temperature increasing, following a 10-minute dwell time cold. The upward rate was 1-3 degrees/minute. The loads on the sample were minimal, being about 275-3450 Pa (0.04-0.5 psi). By increasing the load by a hundred, slightly smaller strains and LCTE's were obtained, so that pressure is a factor.

There are three kinds of pressing used to compact the samples. "Isostatic" or "billet" pressing is pressing done in a fluid with molding powder placed in a sack and situated so hydrostatic pressure may be applied relatively uniformly to all sides. Once pressed, the billet then must be machined into finished parts. Parts produced in this way tend to show the least amount of anisotropy, on average. A second technique, also using hydrostatic fluid, includes the use of a mandrel inside the sack, which causes the powder to be roughly shaped around it. This technique produces parts that are roughly pre-shaped and that may be subsequently machined. Parts such as these tend to show much more directionality than do those produced using the first pressing technique and are called "quasi-isostatic". Finally, "ram" or "die" pressed refers to parts pressed directly to their final size using small and relatively inexpensive pistons and cylinders. No subsequent machining is needed and the products tend to be anistropic with considerable variability.

\section{Pristine Results}

Ten years worth of measurements are condensed into Table 1. Samples are "pristine", meaning that no significant rachet growth is thought to have occurred prior to testing. The cold temperature at $-55^{\circ} \mathrm{C}$ represents the low end of the temperature spectrum, and $+75{ }^{\circ} \mathrm{C}$ represents the high end. Linear strain, referenced to $21{ }^{\circ} \mathrm{C}$ on the first up-cycle, is the baseline. The ability to compare results to the liquid immersion densities determined by Baytos [5] justifies the conversion of strain data into densities. 
Table 1. TMA/DIC linear strain data collected for this paper. The liquid immersion results of Baytos are also included.

\begin{tabular}{|c|c|c|c|c|c|c|c|c|}
\hline \multirow{7}{*}{$\begin{array}{l}\text { LX-17, 1st } 4 \\
\text { isostatic } \\
\text { TMA and } \\
\text { DIC } \\
\text { ram }\end{array}$} & \multirow{2}{*}{$\begin{array}{l}\text { Density } \\
\left(\mathrm{g} \mathrm{cm}^{-3}\right)\end{array}$} & \multirow{2}{*}{$\begin{array}{l}\text { Ave. } \\
\text { Linear } \\
\text { Strain } \\
\text { at }-55^{\circ} \mathrm{C}\end{array}$} & \multicolumn{3}{|c|}{$\begin{array}{l}\text { Density } \\
\left(\mathrm{g} \mathrm{cm}^{-3}\right)\end{array}$} & \multicolumn{3}{|c|}{ Ave. LCTE $\left(\times 10^{-6}{ }^{\circ} \mathrm{C}^{-1}\right)$} \\
\hline & & & at $75^{\circ} \mathrm{C}$ & $-55^{\circ} \mathrm{C}$ & $75^{\circ} \mathrm{C}$ & $-55^{\circ} \mathrm{C}$ & $21{ }^{\circ} \mathrm{C}$ & $75^{\circ} \mathrm{C}$ \\
\hline & 1.90 & $-3.5 \mathrm{E}-03$ & $4.0 \mathrm{E}-03$ & 1.919 & 1.875 & 34 & 61 & 110 \\
\hline & 1.90 & $-3.7 \mathrm{E}-03$ & $4.6 \mathrm{E}-03$ & 1.921 & 1.874 & 47 & 59 & 111 \\
\hline & 1.90 & $-3.7 \mathrm{E}-03$ & $4.1 \mathrm{E}-03$ & 1.922 & 1.877 & 36 & 63 & 92 \\
\hline & 1.894 & $-3.8 \mathrm{E}-03$ & $4.7 \mathrm{E}-03$ & 1.916 & 1.868 & 47 & 64 & 108 \\
\hline & 1.90 & $-3.5 \mathrm{E}-03$ & $4.6 \mathrm{E}-03$ & 1.920 & 1.874 & 20 & 69 & 103 \\
\hline PBX 9502 & 1.885 & $-3.4 \mathrm{E}-03$ & $3.4 \mathrm{E}-03$ & 1.904 & 1.866 & 40 & 53 & 85 \\
\hline quasi-static & 1.894 & $-3.9 \mathrm{E}-03$ & $3.9 \mathrm{E}-03$ & 1.916 & 1.872 & 50 & 62 & 96 \\
\hline TMA; all & 1.894 & $-4.0 \mathrm{E}-03$ & $3.9 \mathrm{E}-03$ & 1.917 & 1.872 & 48 & 58 & 84 \\
\hline nine are & 1.890 & $-3.6 \mathrm{E}-03$ & $3.6 \mathrm{E}-03$ & 1.911 & 1.870 & 44 & 58 & 91 \\
\hline hemispheres & 1.891 & $-3.8 \mathrm{E}-03$ & $3.9 \mathrm{E}-03$ & 1.913 & 1.869 & 49 & 57 & 90 \\
\hline & 1.891 & $-3.5 \mathrm{E}-03$ & 3.7E-03 & 1.911 & 1.870 & 45 & 51 & 88 \\
\hline & 1.888 & $-3.8 \mathrm{E}-03$ & $3.7 \mathrm{E}-03$ & 1.909 & 1.867 & 51 & 54 & 87 \\
\hline & 1.885 & $-3.7 \mathrm{E}-03$ & $3.4 \mathrm{E}-03$ & 1.906 & 1.866 & 48 & 53 & 76 \\
\hline & 1.891 & $-3.5 \mathrm{E}-03$ & $3.6 \mathrm{E}-03$ & 1.911 & 1.871 & 48 & 50 & 86 \\
\hline PBX 9502 & 1.874 & & & 1.892 & 1.858 & & & \\
\hline liquid & 1.883 & & & 1.901 & 1.868 & & & \\
\hline immersion & 1.875 & & & 1.897 & 1.860 & & & \\
\hline [ref. 5] & 1.883 & & & 1.902 & 1.867 & & & \\
\hline & 1.891 & & & 1.907 & 1.871 & & & \\
\hline & 1.891 & & & 1.907 & 1.871 & & & \\
\hline ufTATB, ram & 1.80 & $-4.2 \mathrm{E}-03$ & $4.4 \mathrm{E}-03$ & 1.823 & 1.777 & 50 & 64 & 96 \\
\hline TMA \& DIC & 1.80 & $-3.8 \mathrm{E}-03$ & $4.1 \mathrm{E}-03$ & 1.821 & 1.778 & 43 & 61 & 93 \\
\hline
\end{tabular}

Table 2 summarizes the averaged isotropic results, cold and hot, for samples of the nominal ambient values, and these may be used as code input for generic material. If the densities are different from the nominal, then the fractional density may be used to estimate. Interpolating may be done using a secondorder polynomial fit to the $-55,21$ and $75^{\circ} \mathrm{C}$ points for each property by itself. For example, the densities become

$$
\begin{aligned}
& \rho_{o}(L X-17) \approx 1.9075-3.20 \times 10^{-4} T-1.68 \times 10^{-6} T^{2} \\
& \rho_{o}(P B X 9502) \approx 1.8965-2.77 \times 10^{-4} T-1.56 \times 10^{-6} T^{2} \\
& \rho_{o}(\text { ufTATB }) \approx 1.8071-3.20 \times 10^{-4} T-9.07 \times 10^{-7} T^{2}
\end{aligned}
$$


across the temperature range. It is not possible to take a second-order fit of the strain, differentiate it and get good values for the LCTE. The LCTE's must be interpolated separately.

Table 2. Summarized isotropic thermal expansion results at cold and hot temperatures.

\begin{tabular}{cccccc}
\hline & \multicolumn{3}{c}{$\begin{array}{c}\text { Linear Strain } \\
\left(\mathrm{x} 10^{-3}\right)\end{array}$} & \multicolumn{3}{c}{ Density $\left(\mathrm{g} \mathrm{cm}^{-3}\right)$} \\
\cline { 2 - 6 } & $\begin{array}{c}\text { Density } \\
\left(\mathrm{g} \mathrm{cm}^{-3}\right)\end{array}$ & at $-55^{\circ} \mathrm{C}$ & at $75^{\circ} \mathrm{C}$ & $-55^{\circ} \mathrm{C}$ & $75^{\circ} \mathrm{C}$ \\
\hline LX-17 & 1.90 & $-3.7 \pm 0.2$ & $4.3 \pm 0.4$ & $1.920 \pm 0.01$ & $1.874 \pm 0.01$ \\
PBX 9502 & 1.89 & $-3.7 \pm 0.2$ & $3.7 \pm 0.3$ & $1.907 \pm 0.005$ & $1.867 \pm 0.005$ \\
ufTATB & 1.80 & $-4.0 \pm 0.2$ & $4.2 \pm 0.2$ & $1.822 \pm 0.01$ & $1.778 \pm 0.01$ \\
\hline & Ave. LCTE $\left(\times 10^{-60} \mathrm{C}^{-1}\right)$ & & \multicolumn{2}{c}{ Fractional Density } \\
\cline { 2 - 6 } & $-55^{\circ} \mathrm{C}$ & $21^{\circ} \mathrm{C}$ & $75^{\circ} \mathrm{C}$ & $-55^{\circ} \mathrm{C}$ & $75^{\circ} \mathrm{C}$ \\
\hline LX-17 & $41 \pm 8$ & $62 \pm 8$ & $105 \pm 15$ & & $0.988 \pm 0.006$ \\
PBX 9502 & $46 \pm 5$ & $54 \pm 5$ & $87 \pm 10$ & $1.010 \pm 0.006$ & \\
ufTATB & $46 \pm 10$ & $62 \pm 10$ & $94 \pm 15$ & &
\end{tabular}

Table 3 summarizes the directional differences seen in various samples, including two from the literature $[3,7]$. The top part includes individual cylindrical samples, which have been measured axially and diametrally. Because the parts were made by different processes, it is not surprising that the axial/diametral ratios vary considerably. The lower part of Table 3 contains axially-measured samples taken from large quasi-isostatic parts cut into many smaller parts. The lower result is data taken for this report.

Table 3. Directional thermal expansion differences seen in LX-17 and PBX 9502. LCTE is in $\times 10^{-6}{ }^{\circ} \mathrm{C}^{-1}$.

\begin{tabular}{lccccccc}
\hline & $\begin{array}{c}\text { Temp } \\
\left({ }^{\circ} \mathrm{C}\right)\end{array}$ & $\begin{array}{c}\text { Strain } \\
\text { Axial }\end{array}$ & $\begin{array}{c}\text { Strain } \\
\text { Diametral }\end{array}$ & $\begin{array}{c}\text { LCTE } \\
\text { Axial }\end{array}$ & $\begin{array}{c}\text { LCTE } \\
\text { Diametral }\end{array}$ & $\begin{array}{c}\text { ratio } \\
\text { strain }\end{array}$ & $\begin{array}{c}\text { ratio } \\
\text { LCTE }\end{array}$ \\
\hline LX-17 ram- & -55 & $-4.11 \mathrm{E}-03$ & $-3.13 \mathrm{E}-03$ & 23 & 19 & 1.3 & 1.2 \\
pressed, DIC & 21 & 0 & 0 & 79 & 63 & & 1.3 \\
& 75 & $5.12 \mathrm{E}-03$ & $4.26 \mathrm{E}-03$ & 119 & 95 & 1.2 & 1.3 \\
PBX 9502 [7] & -55 & & & 64 & 39 & & 1.6 \\
quasi-isostatic & 75 & & & 125 & 68 & & 1.8 \\
ufTATB ram- & -55 & $-6.27 \mathrm{E}-03$ & $-2.94 \mathrm{E}-03$ & 71 & 24 & 2.1 & 3.0 \\
pressed, DIC & 21 & 0 & 0 & 102 & 45 & & 2.3 \\
& 75 & $6.86 \mathrm{E}-03$ & $3.11 \mathrm{E}-03$ & 146 & 73 & 2.2 & 2.0 \\
\hline & & Strain & Strain & LCTE & LCTE & ratio & ratio \\
& & Radial & Transverse & Radial & Transverse & strain & LCTE \\
\hline PBX 9502 [3] & -40 & & & 50 & 42 & & 1.2 \\
quasi-isostatic & 20 & & & 66 & 56 & & 1.2 \\
& 60 & & & 84 & 73 & & 1.2 \\
PBX 9502 & -55 & $-4.41 \mathrm{E}-03$ & $-3.32 \mathrm{E}-03$ & 57 & 43 & 1.3 & 1.3 \\
quasi-isostatic & 21 & 0 & 0 & 66 & 47 & & 1.4
\end{tabular}




\section{Thermal Cycling}

A considerable number of measurements were done for this paper. Table 4 contains LX-17 and PBX 9502 data for samples that were thermal-cycled and had their densities measured at room temperature on the down side of every cycle. The swelling appears to approach about 1-1.5 volume $\%$. Table 5 shows the strain and LCTE results for a cycled LX-17 sample. The strain (swelling) increases with each cycle but the LCTE is constant at cold and ambient and decreases slightly hot. This shows that using only LCTE values can be misleading.

All this data is combined with that of Rizzo [1] and Johnson [8] to give Figure 2. This displays final fractional densities from samples thermal-cycled 20 or more times so that the result is perhaps equilibrated. The X-axis is the temperature span of the thermal cycle from bottom to top each time. The four kinds of symbols show what the initial temperature was. Figure 3 shows that the larger the temperature span, the more rachet growth is obtained.

A special run was done to consider the properties of Kel-F 800. Old samples of LX-17-1 were heated to $100{ }^{\circ} \mathrm{C}$ for 24 hours to remove all races of crystallinity in the binder. The samples were then cooked at $40{ }^{\circ} \mathrm{C}$ for various times, because this temperature is where Kel-F crystals grow most rapidly. Strain was then measured with the Ares G2 at room temperature. No effects on the sample strain or LCTE were seen. 
Table 4. Rachet growth in samples with room temperature density measured after every cycle. All cycles are $-50{ }^{\circ} \mathrm{C}$ to $70{ }^{\circ} \mathrm{C}$.

\begin{tabular}{|c|c|c|c|c|c|c|c|}
\hline $\begin{array}{l}\text { Cycle } \\
\text { No. }\end{array}$ & $\begin{array}{c}\text { End } \\
\text { Density }\end{array}$ & $\begin{array}{l}\text { Cycle } \\
\text { No. }\end{array}$ & $\begin{array}{c}\text { End } \\
\text { Density }\end{array}$ & $\begin{array}{l}\text { Cycle } \\
\text { No. }\end{array}$ & $\begin{array}{c}\text { End } \\
\text { Density }\end{array}$ & $\begin{array}{c}\text { Cycle } \\
\text { No. }\end{array}$ & $\begin{array}{c}\text { End } \\
\text { Density }\end{array}$ \\
\hline \multicolumn{2}{|c|}{ LX-17, ram, } & 0 & 1.910 & 3 & 1.901 & 5 & 1.898 \\
\hline \multicolumn{2}{|c|}{$25.4 \times 12.7 \mathrm{~mm}$} & 2 & 1.903 & 4 & 1.900 & 6 & 1.898 \\
\hline 0 & 1.918 & 3 & 1.902 & 5 & 1.899 & \multicolumn{2}{|c|}{ PBX 9502, ram, } \\
\hline 1 & 1.917 & 4 & 1.900 & 6 & 1.897 & \multicolumn{2}{|c|}{$25.4 \times 12.7 \mathrm{~mm}$} \\
\hline 2 & 1.912 & 5 & 1.899 & 7 & 1.896 & 0 & 1.901 \\
\hline 3 & 1.910 & 6 & 1.897 & 8 & 1.896 & 1 & 1.897 \\
\hline 4 & 1.908 & \multicolumn{2}{|c|}{ LX-17, ram, } & 9 & 1.894 & 2 & 1.893 \\
\hline 5 & 1.907 & \multicolumn{2}{|c|}{$25.4 \times 12.7 \mathrm{~mm}$} & 10 & 1.894 & 3 & 1.890 \\
\hline 6 & 1.906 & 0 & 1.896 & 11 & 1.893 & 4 & 1.889 \\
\hline 7 & 1.905 & 1 & 1.891 & 12 & 1.893 & 5 & 1.888 \\
\hline 8 & 1.905 & 2 & 1.887 & 13 & 1.893 & 6 & 1.886 \\
\hline 9 & 1.904 & 3 & 1.884 & 14 & 1.892 & 7 & 1.885 \\
\hline 10 & 1.904 & 4 & 1.882 & 15 & 1.892 & 8 & 1.884 \\
\hline 11 & 1.904 & 5 & 1.880 & 16 & 1.891 & 9 & 1.883 \\
\hline 12 & 1.903 & 6 & 1.879 & 17 & 1.892 & 10 & 1.883 \\
\hline 13 & 1.902 & 7 & 1.878 & 18 & 1.892 & 11 & 1.882 \\
\hline 16 & 1.902 & 8 & 1.877 & 19 & 1.891 & 12 & 1.882 \\
\hline 19 & 1.901 & 9 & 1.876 & 20 & 1.891 & 13 & 1.882 \\
\hline 22 & 1.900 & 10 & 1.876 & 23 & 1.890 & 14 & 1.881 \\
\hline 28 & 1.899 & 11 & 1.875 & 26 & 1.889 & 15 & 1.881 \\
\hline 34 & 1.898 & 12 & 1.875 & 29 & 1.889 & 16 & 1.881 \\
\hline 40 & 1.897 & 13 & 1.875 & 32 & 1.888 & 17 & 1.881 \\
\hline \multicolumn{2}{|c|}{ LX-17, ram, } & 16 & 1.874 & 35 & 1.888 & 18 & 1.880 \\
\hline \multicolumn{2}{|c|}{$19.05 \times 12.7 \mathrm{~mm}$} & 19 & 1.872 & 41 & 1.887 & 19 & 1.881 \\
\hline 0 & 1.915 & 22 & 1.872 & 47 & 1.887 & 22 & 1.880 \\
\hline 2 & 1.906 & 28 & 1.871 & 53 & 1.886 & 25 & 1.879 \\
\hline 4 & 1.900 & 34 & 1.869 & \multicolumn{2}{|c|}{ LX-17, isostatic, } & 28 & 1.880 \\
\hline 5 & 1.899 & 40 & 1.869 & $25.4 \mathrm{x}$ & $.7 \mathrm{~mm}$ & 31 & 1.879 \\
\hline 6 & 1.898 & \multicolumn{2}{|c|}{ LX-17, isostatic, } & 0 & 1.915 & 34 & 1.879 \\
\hline 7 & 1.896 & \multicolumn{2}{|c|}{$25.4 \times 12.7 \mathrm{~mm}$} & 1 & 1.909 & 40 & 1.879 \\
\hline 8 & 1.895 & 0 & 1.914 & 2 & 1.906 & 46 & 1.878 \\
\hline \multirow{2}{*}{\multicolumn{2}{|c|}{$\begin{array}{l}\text { LX-17, ram, } \\
19.05 \times 12.7 \mathrm{~mm}\end{array}$}} & 1 & 1.909 & 3 & 1.902 & 52 & 1.878 \\
\hline & & 2 & 1.904 & 4 & 1.901 & & \\
\hline
\end{tabular}


Table 5. Rachet growth as measured from strain and LCTE for PBX 9502 between $-54{ }^{\circ} \mathrm{C}$ to $74{ }^{\circ} \mathrm{C}$. The data is extrapolated 1 degree to either side. The initial density was $1.894 \mathrm{~g} / \mathrm{cm}^{3}$, a cylinder 25.4 x $12.7 \mathrm{~mm}$, isostatically-pressed and measured by TMA.

\begin{tabular}{ccccccc}
\hline & \multicolumn{3}{c}{$\begin{array}{c}\text { Strain } \\
\left(\mathrm{x} 10^{-3}\right)\end{array}$} & \multicolumn{4}{c}{ LCTE $\left(\times 10{ }^{\circ} \mathrm{C}^{-1}\right)$} \\
\cline { 2 - 7 } cycle & est & & est & est & est \\
no. & $-55{ }^{\circ} \mathrm{C}$ & $21{ }^{\circ} \mathrm{C}$ & $75{ }^{\circ} \mathrm{C}$ & $-55^{\circ} \mathrm{C}$ & $21{ }^{\circ} \mathrm{C}$ & $75{ }^{\circ} \mathrm{C}$ \\
\hline 1 & -3.8 & 0.0 & 4.5 & 47 & 64 & 108 \\
2 & -3.0 & 0.77 & 5.0 & 48 & 64 & 94 \\
3 & -2.6 & 1.2 & 5.4 & 50 & 65 & 90 \\
4 & -2.2 & 1.6 & 5.8 & 47 & 63 & 79 \\
5 & -1.9 & 1.9 & 6.1 & 47 & 63 & 81 \\
6 & -1.6 & 2.1 & 6.3 & 47 & 61 & 84 \\
7 & -1.4 & 2.4 & 6.5 & 46 & 63 & 80 \\
8 & -1.3 & 2.6 & 6.6 & 45 & 63 & 84 \\
9 & -1.2 & 2.7 & 6.8 & 47 & 63 & 88 \\
10 & -1.0 & 2.8 & 6.9 & 46 & 62 & 84 \\
11 & -0.85 & 3.0 & 7.2 & 48 & 63 & 79
\end{tabular}

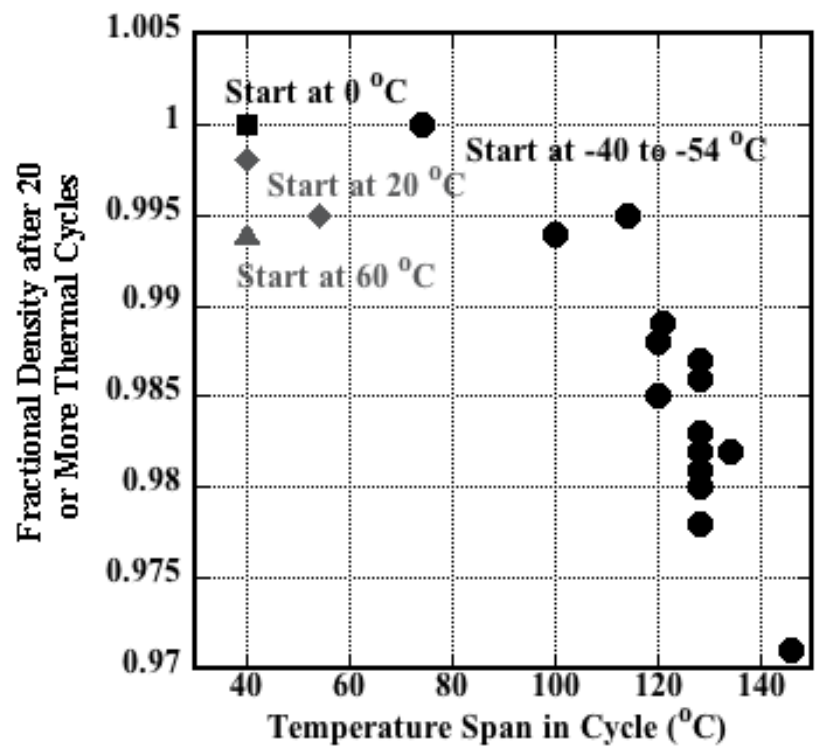

Figure 2. The fractional density in rachet growth increases with the temperature span.

Figure 2 shows that pressure applied to the sample during rachet growth helps to suppress the effect. The data seems to suggest that pressure is more effective on LX-17 growth than on PBX 9502. Other samples were subjected to $5170 \mathrm{kPa}(750 \mathrm{psi})$ to study creep. At 25,50 and $75^{\circ} \mathrm{C}$, the fractional density change after 4 weeks was 1.000, 0.999 and 0.997. 


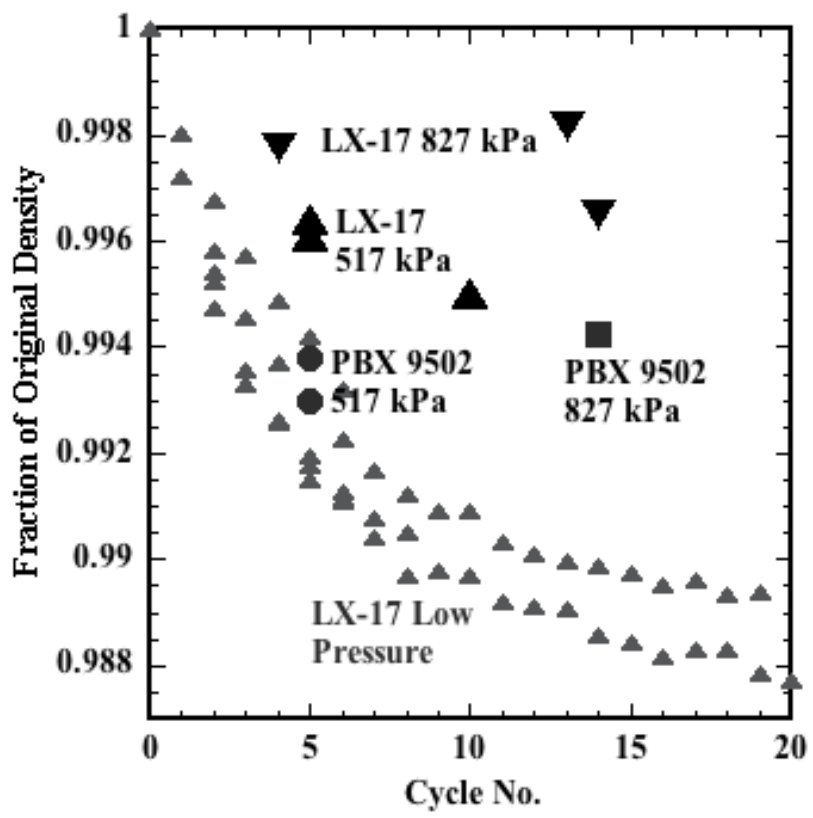

Figure 3. Effect of $517 \mathrm{kPa}(75 \mathrm{psi})$ and $827 \mathrm{kPa}(120 \mathrm{psi})$ on fractional density of rachet growth. LX-17 at low pressure is shown by the small triangles.

Finally, Kel-F 800 was run for linear strain, which is shown in Figure 4. The downward turn could be caused by sample softening with the probe sinking in. The linear strain at $-55^{\circ} \mathrm{C}$ and $75{ }^{\circ} \mathrm{C}$ is $-3.9 \times 10^{-3}$ and $1.9 \times 10^{-3}$, with the high temperature point being uncertain. These axial strains were tripled for volumetric use; there being no diametral data. If we use Dobratz' ambient density of $2.02 \mathrm{~g} / \mathrm{cm}^{3}$ [9], we get cold and hot values of 2.044 and $2.009 \mathrm{~g} / \mathrm{cm}^{3}$. 


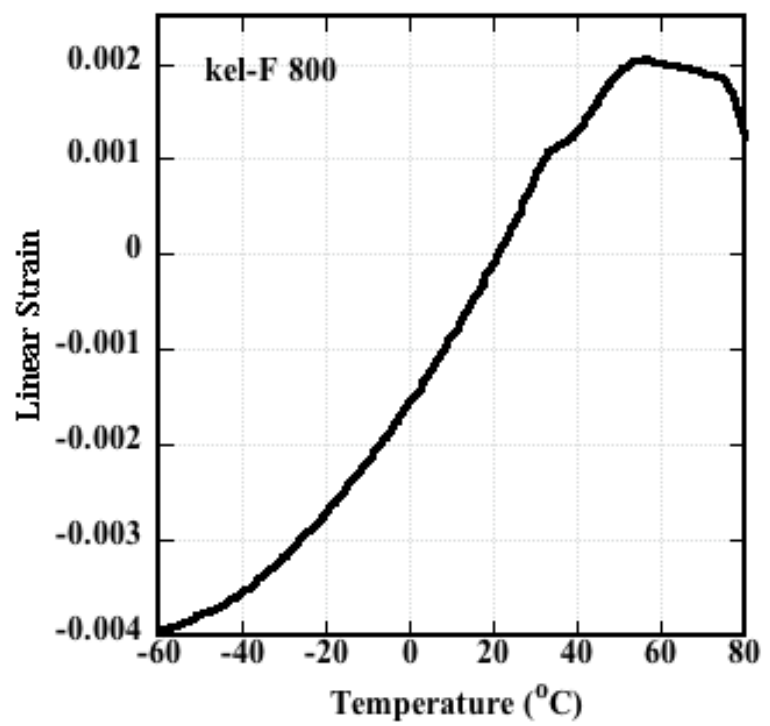

Figure 4. Linear strain curve for Kel-F 800.

We move one step further and consider the X-Ray diffraction data of Kolb and Rizzo [10]. They measured the unit cell volumes, which can be converted to density knowing that there are two molecules per unit cell in the triclinic structure [11]. We also assume that the Kel-F data is theoretically dense, which is not quite true because of an amorphous component. The resulting maximum densities are listed in Table 6.

Table 6. Theoretical maximum densities (TMD) measured for TATB and calculated for LX-17 and PBX 9502.

\begin{tabular}{|c|c|c|c|}
\hline \multirow{2}{*}{$\begin{array}{c}\text { Temp } \\
\left({ }^{\circ} \mathrm{C}\right)\end{array}$} & \multicolumn{3}{|l|}{$\begin{array}{l}\text { TMD (g } \\
\left.\mathrm{cm}^{-3}\right)\end{array}$} \\
\hline & TATB & LX-17 & PBX 9502 \\
\hline-55 & 1.972 & 1.977 & 1.975 \\
\hline 21 & 1.936 & 1.942 & 1.940 \\
\hline 75 & 1.900 & 1.908 & 1.905 \\
\hline
\end{tabular}

\section{Discussion and Summary}

By converting strain to density, the strain and liquid immersion results agree and the thermal expansion of TATB no longer seems elusive. The combined LCTE data has smaller error bars, partly because the 
three explosives considered here are precisely made, compared to an arbitrary large-grained TATB. Directional effects must be accounted for in any sample if the final step to density is to be made.

The greatest gap in the data lies in the ram-pressed area, where the difference in axial and diametral measurements is clearly a function of how the pressing is done. A complete study should be done in this area. Quasi-isostatic data on LX-17 to balance all that taken on PBX 9502 would also be good.

There is a bewildering array of rachet growth-as-a-function-of-pressure data, which is insufficient to predict what will happen to a given small sample. Remaining "pristine" can hold for several cycles with a wide temperature spread and it takes 20 cycles or more to greatly change the density. A systematic study of the kind done by Rizzo [1] should be undertaken.

\section{References}

[1] H. F. Rizzo, J. R. Humphrey and J. R. Kolb, "Growth of 1,3,5-Triamino-2,4,6-Trinitrobenzene (TATB) I. Control of Growth by use of High Tg Polymeric Binders," Propellants and Explosives, 1981, 6, 2736.

[2] H. F. Rizzo, J. R. Humphrey and J. R. Kolb, "Growth of 1,3,5-Triamino-2,4,6-Trinitrobenzene (TATB) II. Control of Growth by use of High Tg Polymeric Binders," Propellants and Explosives, 1981, 6, 5762.

[3] Howard H. Cady, Los Alamos National Laboratory, private communication in C. B. Skidmore, T. A. Butler and C. W. Sandoval, The Elusive Coefficients of Thermal Expansion in PBX 9502, Los Alamos National Laboratory report LA-14003, January, 2003.

[4] C. B. Skidmore, T. A. Butler and C. W. Sandoval, The Elusive Coefficients of Thermal Expansion in $P B X$ 9502, Los Alamos National Laboratory report LA-14003, January, 2003.

[5] J. F. Baytos and C. A. Martinez, "Techniques for Measurement of Densities of PBX Samples at Other than Room Temperature," Los Alamos National Laboratory report LA-7450-MS, August, 1978.

[6] F. C. Nix and D. MacNair, "The Thermal Expansion of Pure Metals: Copper, Gold, Aluminum, Nickel and Iron," Phys. Rev., 1941, 60, 597-605.

[7] L. G. Hill, J. B. Bdzil and T. D. Aslam, "Front Curvature Rate Stick Measurements and Detonation Shock Dynamics Calibration for PBX 9502 over a Wide Temperature Range," Eleventh International Detonation Symposium, Snowmass Village, CO, August 31-September 4, 1998, pp. 1029-1037.

[8] H. D. Johnson, "Thermal Growth and Mechanical Properties of RX-03-BB," Mason \& Hanger, Silas Mason Co., Pantex Plant report MHSMP-76-17, 1976.

[9] B. M. Dobratz and P. C. Crawford, LLNL Explosives Handbook, LLNL report UCRL-52997 Rev 2, January 31, 1985, p. 19-61.

[10] J. R. Kolb and H. F. Rizzo, "Growth of 1,3,5-Triamino-2,4,6-trinitrobenzene (TATB). I. Anisotropic Thermal Expansion," Propellants and Explosives, 1979, 4, 10-16.

[11] H. H. Cady and A. C. Larson, "The Crystal Structure of 1,3,5-Triamino-2,4,6-Trinitrobenzene," Acta Crystallographica, 1965, 18, 485-496.

\section{Acknowledgments}

This work performed under the auspices of the U.S. Department of Energy by Lawrence Livermore National Laboratory under Contract DE-AC52-07NA27344 